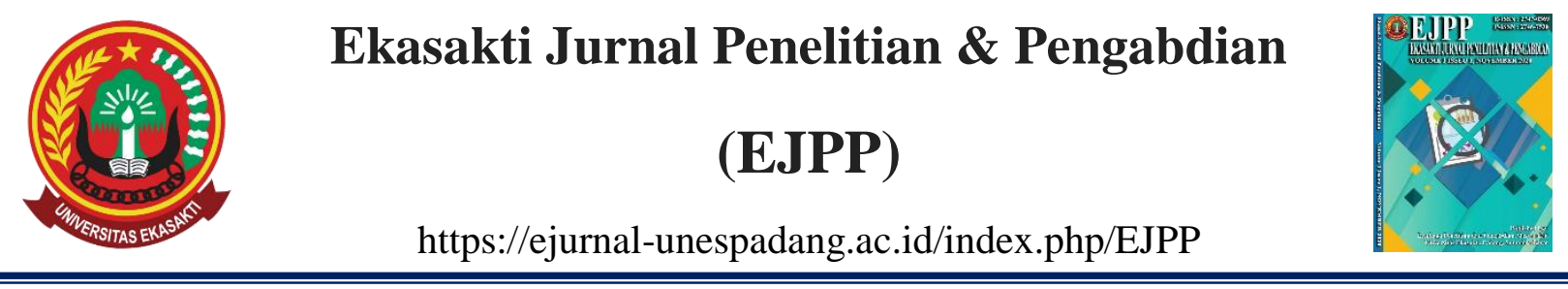

\title{
THE IMPACT OF OWNERSHIP STRUCTURE AND CAPITAL STRUCTURE ON FIRM'S VALUE
}

\author{
Silvi Delfiani ${ }^{1}$, Mohamad Fany Alfarisi ${ }^{2}$ \\ 1) Universitas Putra Indonesia YPTK, Padang, \\ Email: silvidelfiani@upiyptk.ac.id \\ 2) Universitas Andalas, Padang, \\ Email: mfany@eb.unand.ac.id
}

\begin{tabular}{ll} 
ARTICLE INFO \\
\hline Received & $: 23 / 10 / 2021$ \\
Revised & $: 29 / 10 / 2021$ \\
Publish & $: 10 / 11 / 2021$
\end{tabular}

\begin{abstract}
The objective of the present study is to investigate the impact of insider ownership, institutional ownership and capital structure on firm's value. The population of this study is all manufacturing companies which are listed in Indonesia Stock Exchange (IDX) in the period of 2011-2016. We use panel data regression with 174 observations. For hypothesis testing, the present study employs the t-test with $\alpha 10 \%$ level of significance. The results suggest that institutional ownership and firm size have significant impact on firm's value.
\end{abstract}

\section{Keywords:}

Insider Ownership, Institutional Ownership,

Capital Structure, Firm Value

DOI: https://doi.org/10.31933/ejpp.v2i1.410

\section{INTRODUCTION}

Investors normally seek to find stocks that can benefit them most. The benefit can be in the form of dividend or capital gains. Higher return on stock investment earned by shareholders indicates that they are wealthier. The prosperity makes the company's value high. Firm value can be observed from its stock market price. Therefore, the higher the stock price of a company, the higher the value of the company. Firm value can be increased if the manager as an agent who runs the firm creates policies that in line with the shareholders objectives. Sometimes manager's goals are different from shareholders. This condition is due to managers do not own the firm's shares. With that in mind, the condition is known as agency conflict.

If agency conflict can be minimized, it will ultimately contribute to the rising of firm's value. Wahyudi and Pawestri (2006) argue that agency conflict can be influenced by ownership structure. Moreover, other researchers argue that agency conflict can influence the course of a company and ultimately affect its performance. Jensen and Meckling (1976) states that an increase in managerial ownership can reduce agency conflict because manager not only act as a decision maker but also as an owner of the firm. 
As far as the institutional ownership is concerned, Asmawati and Amanah (2013) argue that higher stake of institutional ownership will result in more monitoring activities. It is expected that institutional investors can elimate the opportunistic behavior of and fraund committed by management.

Debt is another mechanism that can be used to reduce agency problem (Masdupi, 2005). Jensen (1986) states that debt can be used to control the use of free cash flow which is the amount of excessive cash generated by a company at the end of the period, so it might increase the value of the firm (Wardani \& Hermuningsih, 2011)

Some researchers have conducted research on this topic and still show different results such as Abukosim et al. (2014), Dewi and Abundanti (2019), Lawal (2014), Ramadan (2015), Kodongo et al. (2014), Sujoko and Soebiantoro (2007) and Dewi and Wirajaya (2013). Abukosim et al., (2014) finds that managerial ownership and concentrated ownership have no positive impact on firm's value, while other variables of institutional ownership and foreign ownership have positive and significant influence on firm value. Dewi and Abundanti (2019) suggests different results that only profitability and managerial ownership have a positive and significant effect on firm value, while liquidity and institutional ownership have a negative effect on firm value.

Lawal (2014) conducts research on capital structure and firm's value. The results of the study exhibit that debt plays a major role in increasing the value of the company. But the results of this study differ from Kodongo et al. (2014) that suggests leverage has no significant impact on firm's value.

Furthermore, research conducted by Sujoko and Soebiantoro (2007), the results of the study found that institutional ownership, interest rates, state of the capital market, market growth, profitability, dividend, firm size and leverage affect firm value while managerial ownership variable are not affect the value of the company. Research conducted by Dewi and Wirajaya (2013) has different results with previous researchers. The result of research stated that capital structure and profitability have an effect on the value of the company. However, the size of the company does not affect the company's value. Research results conducted by previous researchers there are differences. Therefore, this study conducts further research on the effect of managerial ownership, institutional ownership and capital structure using firm size as a control variable to firm value on manufacturing companies listed on Indonesia Stock Exchange period 2011-2016.

\section{RESEARCH METHODOLOGY Population and Sample}

In the Indonesian stock market, the industry is dividend into nine sectors. One of them is manufacturing sector. The manufacturing sector is subdivided over sub-sectors. Viewed from the entire sector, the manufacturing sector has the largest sub-sector compared to other sectors. Thus, companies incorporated in the manufacturing industry not only come from one industry but also form different industries. The diversity of the types of companies in this sector is expected to focus on one industry but form various industries. 
The population in this study are all companies incorporated in the manufacturing sector listed on the 2011-2016 period of BEI which totals 126 companies. During the six years of observation there were 756 observations that were the total of the study population. The selected sample is 30 companies that is 180 observations by using purposive sampling method.

\section{Operational Definition and Variable Measurement}

Dependent variable in this research is firm value. Independent variables in this study are managerial ownership, institutional ownership, and capital structure. While the size of the company as a control variable.

The value of the firm is the price that potential buyers are willing to pay if the company is sold which is reflected in the stock price. According to Gill and Obradovich (2012) Torbin's Q can be used as a measure of company value, by the formula:

$$
Q=\frac{M V E+D}{T A}
$$

Type :

Q : Firm Value

MVE : Market Value of Equity

D : The book value of total debt

TA : The book value of total assets

Managerial ownership is the percentage of ownership of shares owned by the managerial side is the directors and commissioners as policy makers. According to Rustendi and Jimmi (2008) managerial ownership can be calculated by percentage comparison of total shares of managerial parties with total shares outstanding (Wiranata \& Nugrahanti, 2013).

$$
I N S D R=\frac{\text { share of managerial ownership }}{\text { common stocks outstanding }} \times 100 \%
$$

Institutional ownership is the percentage of ownership of shares owned by institutional parties. The term institutional here means the institutions of both government and private institutions residing in the country. According Ujiyantho and Pramuka (2007) institutional ownership can be calculated by using the ratio between the number of shares owned by the institutional to the total number of shares outstanding as a whole (Wiranata \& Nugrahanti, 2013).

$$
I N S T=\frac{\text { share of institutional ownership }}{\text { common stocks outstanding }} \times 100 \%
$$

Capital structure is the ratio between the total debt with the total capital used by the company to fund its operational activities. According Ogolmagai (2013) debt to equity ratio can be used as a measure of capital structure, by the formula:

$$
\text { Debt to Equity Ratio }=\frac{\text { Debt }}{\text { Equity }} \times 100 \%
$$


Firm size shows the size of a company that can be seen from the total assets owned. According to Sari (2012) firm size can be measured through total assets (Sholekah \& Venusita, 2014) with the equation:

$$
S I Z E=\ln \text { Total Aset }
$$

\section{RESULTS AND DISCUSSION}

Initial samples in this study amounted to 30 companies during six years of observation so that obtained 180 observations. Based on the test outlier there are six observations that are considered outlier so that the final sample of the study amounted to 174 observations

Data analysis technique used in this research using regression analysis of panel data. The hausman test is use to determine the best model between fixed effect and random effect. Based on Hausman Test results in Tabel 1, the probability value of F-stat is 0.5998. the probability value of F-stat is greater than the significant level $(\alpha=0.05)$, so the better estimation model used in this research is the Random Effect model.

Tabel 1. Hausman Test

\begin{tabular}{|c|c|c|c|c|}
\hline \multicolumn{5}{|c|}{ Coefficients } \\
\hline & (b) & (B) & $(b-B)$ & sqrt(diag(V_b-V_B)) \\
\hline & Fixed & random & Difference & S.E. \\
\hline INSDR & 1,685 & 2,227 & $-0,542$ & 1,611 \\
\hline INST & 1,910 & 0,951 & 0,959 & 0,960 \\
\hline DER & $-0,075$ & $-0,101$ & 0,026 & 0,049 \\
\hline SIZE & 0,092 & 0,126 & $-0,0349$ & 0,108 \\
\hline Test: & \multicolumn{4}{|c|}{ Ho: difference in coefficients not systemic } \\
\hline $\operatorname{chi} 2(4)$ & $=$ & \multicolumn{3}{|c|}{$(b-B)^{\prime}\left[\left(V \_b-V \_B\right)^{\wedge}(-1)\right](b-B)$} \\
\hline & $=$ & \multicolumn{2}{|l|}{2,750} & \\
\hline Prob>chi 2 & $=$ & \multicolumn{2}{|l|}{0,600} & \\
\hline
\end{tabular}

Source : Statistical Result

After finding the best model then tested BLUE assumption. Model in this research use Random Effect model, therefore in this model no longer need to test or overcome BLUE problem. This is because in the Random Effect model already using GLS (Ganeral Least Square) method to overcome this problem.

Table 2. Panel Data Estimation Result with Random Effect Model

\begin{tabular}{lrrrrr}
\hline \multicolumn{2}{l}{ Random-effects GLS regression } & & & & \\
\hline $\mathbf{Q}$ & Coef. & \multicolumn{1}{l}{ Std. Err. } & $\mathbf{z}$ & & $\mathbf{P}>|\mathbf{z}|$ \\
\hline cons & -0.926 & 0.998 & -0.930 & 0.354 \\
\hline INSDR & 2.227 & 1.612 & 1.380 & 0.167 \\
\hline INST & 0.951 & 0.432 & 2.200 & 0.028 \\
\hline DER & -0.101 & 0.064 & -1.590 & 0.113 \\
\hline SIZE & 0.126 & 0.067 & 1.870 & 0.062 \\
\hline R-sq overall & 0.159 & & Prob > chi2 & 0.046 \\
\hline
\end{tabular}

Source: Statistical Result 
Based on the results of the research contained in Table 2, it can be formulated model equations from research in general as follows:

$$
Q=-0.926+2.227 I N S D R+0.951 I N S T-0.101 D E R+0.126 S I Z E
$$

In Table 2, the value of $\mathrm{R} 2$ is 0.1589 or $15.89 \%$. This indicates that the value of companies in manufacturing companies listed on the BEI 2011-2016 can be explained by the variation of three independent variables and one control variable jointly namely managerial ownership, institutional ownership, capital structure and firm size of $15.89 \%$. While the rest, $84.11 \%$ is explained by other variables that are not in the present study. The hypothesis testing (Test $\mathrm{t}$ ) can be done by looking at the $\mathrm{t}$-stat prob. If the small $\mathrm{t}$-stat prob results are small from $\alpha$ (0.10) then it can be concluded that the independent variable influences the dependent variable. The positive managerial coefficient value of 2.227 and the significance of $0.167>0.10$ indicating that managerial ownership has no effect on firm value. The value of the positive institutional coefficient of 0.951 nand the significance value of $0.028<0.10$ indicates that there is a positive influence between institutional ownership and firm value. Capital structure has no effect on firm value with negative coefficient of 0.101 with significance of $0.113>0.10$. The size of the firm positively affects the value of the company's positive coefficient 0.126 with significance $0.062<0,10$.

\section{The Effect of Managerial Ownership on Firm Value}

Based on the result of the research, it can be seen that managerial ownership variable (INSDR) has no effect on firm value in manufacturing companies listed on BEI. The results of statistical process show that the value of INSDR coefficient is positive 2.227 and significance value $0.167>0.10$. The value of significance indicates that managerial ownership does not affect the value of the firm with a positive value. That is, changes that occur in the managerial ownership structure of a company either increase or decrease in ownership does not affect the value of the company.

The results of this study are not in line with the research of Gill and Obradovich, (2012) who found a positive relationship between managerial ownership and firm value. Sofyaningsih and Hardiningsih (2011) explained that firms that have higher managerial ownership shares tend to have higher stock market values, proving that agency conflict can be overcome by incorporating managers into the company's shareholding structure. Agency conflict occurs when there is a difference of interest between manager and shareholder. According to Sholekah and Venusita (2014) managerial ownership will align the interests of managers with shareholders, where managers tend to maximize their performance because they will experience a direct impact of the policy. By increasing ownership of managerial shares will lower the agency cost, which affects the increase in corporate profits. Lucky companies have increased demand for stocks so that the value of the company also increased.

However, the results of this study are in line with the Abukosim et al. (2014), Rustendi and Jimmi (2008) and Adnantara (2013) studies which found that managerial ownership has no positive effect on firm value. Sujoko and Soebiantoro (2007) explained that the absence of influence between managerial ownership and firm value is due to the fact that management has 
no control over the company, they are controlled by the majority shareholder, so management is only an extension of the majority shareholder.

Managerial ownership does not affect the value of the company is likely due to the amount of share ownership owned by the manager at manufacturing companies listed on the Stock Exchange is too small. The average percentage of managerial share ownership of $4.14 \%$ during 2011-2016. This small percentage of managerial share ownership makes the manager as a shareholder will gain a little advantage over the policies and risks that he experienced as a company manager. This makes managers less than optimal in making policies that benefit majority shareholders. Because managers basically have different interests as the owner and controller of the company. If the condition as a shareholder is not profitable, then the manager prefers the decision maker.

\section{The Effect of Institutional Ownership on Firm Value}

Based on the results of data processing conducted shows that institutional ownership has a positive influence with the regression coefficient of 0.951 and the significance value of $0.028<0.10$ on the value of companies in manufacturing companies listed on the BEI. The value of significance indicates that institutional ownership affects firm value with positive correlations. That is, the more the number of stake ownership by the institution will increase the value of the company.

The results of this study are relevant to research conducted by Abukosim et al. (2014) who found that institutional ownership positively affects the firm's value. As the percentage of institutional share ownership increases in a company, the more votes and encourages the institution to oversee management performance. As a result give a bigger boost to be able to optimize the company's performance so as to increase the value of the company.

The results of this study are also in line with the results of research conducted by Thanatawee (2014) which shows a positive influence between institutional ownership in the country with the value of the company. This is because domestic institutional share ownership can provide an effective monitoring role. Thus can improve corporate governance and corporate value.

In this research, it is found that institutional ownership has a positive effect on company value. This is because the average percentage of share ownership by the institution. The average percentage of share ownership by the institution is $48.76 \%$ in manufacturing companies listed on the IDX period 2011-2016. The amount of the percentage makes the institution more freely monitor the performance of corporate management as policy makers so as to increase the value of the firm.

\section{The Effect of Capital Structure on Firm Value}

Based on the results of the research can be seen that the capital structure does not affect the value of companies in manufacturing companies listed on the Stock Exchange. This can be seen from the results of statistical process which shows the value of DER coefficient is negative with significance value $0.113>0.10$. The value of significance indicates that there is no 
significant effect between capital structure to firm value with negative value. That is, changes in capital structure both increase and decrease can not affect the value of the company.

The results of this study are not in line with that done by Hermuningsih (2013) and Rustendi and Jimmi (2008) who said that the capital structure has a positive influence on the value of the company. By increasing funding through debt will reduce conflicts between managers and shareholders so as to increase the value of the company. Asmawati and Amanah (2013) also explain the company's ability to meet the needs of funds is very influential in the eyes of investors. Debt use is done to benefit from tax utilization. If the company is able to pay short-term liabilities it will make investors have a good perception of the company so as to increase the value of the company.

However, the results of this study are in line with the research of Ogolmagai (2013), Wardani and Hermuningsih (2011), and Sofyaningsih and Hardiningsih (2011) which proves there is no effect of capital structure on firm value. Masulis (1988) states that debt reduction will not lower stock prices as a proxy of firm value (Wardani \& Hermuningsih, 2011). This is because the economic crisis in the United States in 2008 that impacted the capital market around the world including Indonesia, so that JCI (Composite Stock Price Index) has decreased, but the debt policy has been taken by the company. This creates no effect between debt policy and firm value. Capital structure does not affect the value of the company may be because investors tend to invest in companies that provide good value reflected from the current stock price is not from how much percentage of capital and debt owned by the company.

\section{The Effect of Firm Size on Firm Value}

Based on the results of the research can be seen that the variable size of the company affect the value of companies in manufacturing companies listed on the BEI. These results are evidenced based on statistical data processing showing the SIZE coefficient is positive 0.1257 and significance value $0.062<0.10$. The value of significance indicates that firm size affects firm value with positive value. That is, changes in the size of the company either increase or decrease can affect the value of the company.

The results of this study are in line with research conducted by Cuong (2014) who found that firm size has a positive effect on firm value. The larger the size of the company the higher the value of the company. argue that the larger the size of the company, the higher the level of investor confidence in the company's ability to provide the rate of return on investment.

The existence of the influence between the size of the company and the value of the company is caused because usually large companies tend to have professional managers in managing the company. This will make the value of the company to rise because it is managed by experienced people and has the ability to increase sales but can minimize expenditures that make the company experience profits.

\section{CONCLUSIONS AND RECOMMENDIATIONS}

Using panel data regression analysis on 174 observations on manufacturing firms listed in the Indonesia Stock Exchange during 2011 to 2016, this study provides some empirical findings. First, managerial ownership (INSDR) has no effect on firm value. Second, institutional 
ownership (INST) positively affects the value of companies in manufacturing companies listed on the BEI. INST coefficient is positive value of 0.951 means $1 \%$ increase of shareholding by institutional (INST) hence firm value (Q) will increase equal to 0.951 . Third, the capital structure (DER) does not affect the value of companies in manufacturing companies listed on the Stock Exchange. Finally, firm size affects the value of companies in manufacturing companies listed on the BEI

Several variables in this study have results that reject the hypothesis that has been presented in the previous chapter. Therefore, the researcher can summarize some of the weaknesses in this research which are likely to influence the research result. First, the research sample focused on manufacturing companies and examined as many as 30 companies are used as sample research of all companies listed on the Stock Exchange. Second, the study period is too short for six years, while the longer the observation time then the result obtained can better reflect the actual conditions. Third, the independent variable in this study is only able to explain $15.89 \%$ value of a company. While the rest of $84.11 \%$ is explained by other variables not included in this study.

Based on the limitations of the research that the natural researcher, it can be submitted suggestions to refine the next research. First, it is expected that researchers can further research on factors that effect the value of the company such as changing the object of research in a particular sector, adding to the study period, and using value proxy companies other than Torbin's Q. Secondly, this study uses only four independent variables, while firm value may be influenced by other variables. It is therefore advisable to the next researcher to be able to modify this study by replacing the independent variables used or increasing the number of independent variables so as to reflect its influence on firm value.

\section{REFERENCES}

Abukosim, Mukhtaruddin, Ferina, I. S., \& Nurcahaya, C. (2014). Ownership Structure and Firm Value: Empirical Study on Indonesia Manufacturing Listed Companies. Journal of Arts Science \& Cpmmerce, V(4), 1-15.

Adnantara, K. F. (2013). Pengaruh Struktur Kepemilikan Saham dan Corporate Social Responsibility pada Nilai Perusahaan. Jurnal Buletin Srtudi Ekonomi, 18, 107-113.

Asmawati, \& Amanah, L. (2013). Pengaruh Struktur Kepemilikan, Keputusan Keuangan terhadap Nilai Perusahaan: Profitabilitas sebagai Variabel Moderating. Jurnal Ilmu \& Riset Akuntansi, 2(4).

Dewi, A. S. M., \& Wirajaya, A. (2013). Pengaruh Struktur Modal, Profitabilitas Dan Ukuran Perusahaan Pada Nilai Perusahaan. E-Jurnal Akuntansi, 4(2), 358-372.

Dewi, L. S., \& Abundanti, N. (2019). Pengaruh Profitabilitas, Likuiditas, Kepemilikan Institusional Dan Kepemilikan Manajerial Terhadap Nilai Perusahaan. E-Jurnal $\begin{array}{llll}\text { Manajemen Universitas } \quad \text { Udayana, } & 8(10), & \end{array}$ https://doi.org/10.24843/ejmunud.2019.v08.i10.p12

Gill, A., \& Obradovich, J. (2012). The Impact of Corporate Governance and Financial Leverage on the Value of American Firms. International Research Journal of Finance and Economics, 91, 1-14. 
Hermuningsih, S. (2013). Profitability, Growth Opportunity, Capital Structure and The Firm Value. Bulletin of Monetary, Economics and Banking, 115-136.

Jensen, M. C. (1986). Agency costs of free cash flow, corporate finance, and takeovers. Corporate Bankruptcy, 76(2), 323-329. https://doi.org/10.1017/cbo9780511609435.005

Jensen, M. C., \& Meckling, W. H. (1976). Theory of the firm: Managerial behavior, agency costs and ownership structure. Journal of Financial Economics, 3(4), 305-360. https://doi.org/10.1016/0304-405X(76)90026-X

Kodongo, O., Mokoaleli-Mokolet, T., \& Maina, L. (2014). Capital Structure, Profitability and Firm Value: Panel Evidence of Listed Firms in Kenya. Munich Personal RePEc Archive Paper, 57116.

Masdupi, E. (2005). Analisis Dampak Struktur Kepemilikan Hutang dalam Mengontrol Konflik Keagenan. Jurnal Ekonomi dan Bisnis Indonesia. 20 (1), 57-59.

Lawal, A. I. (2014). Capital Structure and The Value of The Firm : Evidence From The Nigeria Banking Industry. Journal of Accounting and Management, 4(1), 31-41.

Ogolmagai, N. (2013). Leverage Pengaruhnya Terhadap Nilai Perusahaan pada Industri Manufaktur yang Go Public di Indonesia. Jurnal EMBA, 1(3), 81-89.

Ramadan, I. Z. (2015). Leverage and the Jordanian Firms' Value: Empirical Evidence. International Journal of Economics and Finance, 7(4), 75-81. https://doi.org/10.5539/ijef.v7n4p75

Rustendi, T., \& Jimmi, F. (2008). Pengaruh Hutang dan Kepemilikan Manajerial terhadap Nilai Perusahaan pada Perusahaan Manufaktur. Jurnal Akuntansi FE Unsil, 3(1), 411-422.

Sholekah, F. W., \& Venusita, L. (2014). Pengaruh Kepemilikan Manajerial, Kepemilikan Institusional, Leverage, Firm Size, Dan Corporate Social Responsibility Terhadap Nilai Perusahaan Pada Perusahaan High Profile yang Terdaftar di Bursa Efek Indonesia Periode 2008-2012. Jurnal Ilmu Manajemen, 2(3), 795-807.

Sofyaningsih \& Hardiningsih. (2011). Struktur Kepemilikan, Kebijakan Deviden, Kebijakan Utang dan Nilai Perusahaan. Dinamika Keuangan dan Perbankan. 3, 68-87.

Sujoko, \& Soebiantoro, U. (2007). Pengaruh Struktur Kepemilikan Saham, Leverage , Faktor Intern Dan Faktor Ekstern Terhadap Nilai Perusahaan ( Studi empirik pada perusahaan manufaktur dan non manufaktur di Bursa Efek Jakarta ). Jurnal Manajemen Dan Kewirausahaan, 9(1), 41-48.

Thanatawee, Y. (2014). Ownership Structure and Dividend Policy: Evidence from China. International Journal of Economics and Finance, 6(8), 197-204. https://doi.org/10.5539/ijef.v6n8p197

Wahyudi, U., \& Pawestri, H. P. (2006). Implikasi Struktur Kepemilikan Terhadap Nilai Perusahaan: Dengan Keputusan Keuangan Sebagai Variabel Intervening. Simposium $\begin{array}{llllll}\text { Nasional Akuntansi } & 9 & \text { Padang, } & 53, & 160 .\end{array}$ https://doi.org/10.1017/CBO9781107415324.004

Wardani, D. K., \& Hermuningsih, S. (2011). Pengaruh Struktur Kepemilikan Terhadap Nilai Perusahaan dengan Kinerja Keuangan dan Kebijakan Hutang sebagai Variabel Intervening. Jurnal Siasat Bisnis, 15(1), 27-36.

Wiranata, Y. A., \& Nugrahanti, Y. W. (2013). Pengaruh Struktur Kepemilikan Terhadap Profitabilitas Perusahaan Manufaktur di Indonesia. Jurnal Akuntansi Dan Keuangan, 15(1), 15-26. https://doi.org/10.9744/jak.15.1.15-26 